\title{
Analisis dan Perancangan Geographic Information System pada Pelacakan Lokasi Kurir Secara Real Time
} Analysis and Design of Geographic Information System for Courier Location Real Time Tracking

\author{
Muhamad Anbiya Nur Islam ${ }^{1}$, Much Aziz Muslim², Hendi Susanto ${ }^{3}$ \\ 1,2,3 Jurusan Ilmu Komputer, FMIPA, Universitas Negeri Semarang \\ e-mail: ${ }^{1}$ anbiya@ students.unnes.ac.id, ${ }^{2}$ a212muslim@yahoo.com, ${ }^{3}$ hendi.susanto@outlook.com
}

\begin{abstract}
Abstrak
Kecepatan akses informasi menjadi pembahasan cukup penting dalam pembuatan aplikasi. Teknologi yang mulai merambah pada dunia serba mobile menjadikan kecepatan dan kepraktisan akses informasi menjadi prioritas utama dalam pelayanan fitur sebuah aplikasi. Aktivitas logistik yang melibatkan banyak komponen pengguna memerlukan suatu sistem informasi yang dapat memberikan layanan informasi cepat dan akurat. Pada penelitian ini penulis membuat Real time system berbasis Geographic Information System, untuk mengakomodasi kebutuhan komunikasi data lokasi antara kurir dan outlet. Metode yang digunakan dalam penelitian ini memanfaatkan Aplication Programming Interface yang disediakan oleh Google, yaitu Google Maps API. Data spasial yang digunakan pada penelitian ini mengambil dari data Maps milik Google. Hasil penelitian ini adalah suatu sistem yang saling berkomunikasi mengirim data spasial berupa latitude, longitude, distance, time estimation, route, dan real time marker. Penggunaan GIS berbasis Google Maps API ini sangat efektif dalam membantu estimasi dan monitoring proses pengiriman dan jual beli.
\end{abstract}

Kata kunci-Geographic Information System, Google Maps API, Mobile Application, Real Time System

\begin{abstract}
Speed of access to information becomes quite important in the making of the application. The technology that began to penetrate the mobile world makes the speed and practicality of information access a top priority in the service features an application. Logistic activities involving multiple user components require an information system that can provide fast and accurate information services. In this study the authors make Real time system based on Geographic Information System, to accommodate the communication needs of location data between courier and outlet. The method used in this research utilizing Aplication Programming Interface provided by Google, namely Google Maps API. The spatial data used in this study takes from Google's Maps data. The result of this research is a system that communicate to each other send spatial data in the form of latitude, longitude, distance, time estimation, route, and real time marker. The use of Google Maps API-based GIS is very effective in assisting estimation and monitoring of shipping and buying process.
\end{abstract}

Keywords - Geographic Information System, Google Maps API, Mobile Application, Real Time System 


\section{PENDAHULUAN}

Perkembangan ilmu pengetahuan dan teknologi yang pesat sekarang ini, membuat kita untuk lebih membuka diri dalam menerima perubahan-perubahan yang terjadi akibat kemajuan dan perkembangan tersebut. Saat ini telah banyak sistem informasi yang digunakan untuk menunjang dan menyelesaikan suatu permasalahan yang biasanya timbul dalam suatu organisasi, perusahaan atau instansi perusahaan. Sistem informasi diharapkan dapat meningkatkan kinerja dari suatu organisasi ataupun instansi agar lebih efektif dan efisien serta mudah dalam penerimaan informasi yang ingin disampaikan. Begitu juga dalam bidang Sistem Informasi Geografis (SIG) atau Geographic Information System (GIS) yaitu teknologi yang menjadi alat bantu dan sangat esensial untuk menyimpan, memanipulasi, menganalisis dan menampilkan kembali kondisi-kondisi alam dengan bantuan data atribut dan keruangan [1].

Teknologi juga telah merambah kedalam dunia bisnis. Hampir semua perusahaan kini memiliki aplikasi digital [2]. Segala aktivitas perusahaan baik produksi distribusi maupun penjualan, kini dilakukan secara digital. Dalam pelaksanaan segala aktivitas digital tersebut membutuhkan sebuah aplikasi [3].

Geographic Information System (GIS) merupakan sistem yang dirancang untuk bekerja dengan data yang tereferensi secara spasial atau koordinat-koordinat geografi [4]. GIS memiliki kemampuan untuk melakukan pengolahan data dan melakukan operasi-operasi tertentu dengan menampilkan dan menganalisa data. Aplikasi GIS saat ini tumbuh tidak hanya secara jumlah aplikasi namun juga betambah dari jenis keragaman aplikasinya. GIS adalah sistem komputer yang digunakan untuk memasukan (capturing), menyimpan, memeriksa, mengintegrasikan, memanipulasi, menganalisa, dan menampilkan data-data yang berhubungan dengan posisi-posisi di permukaan bumi [5]. GIS adalah kumpulan yang terorganisir dari perangkat keras komputer, perangkat lunak, data geografi dan personal yang dirancang secara efisien untuk memperoleh, menyimpan, mengupdate, memanipulasi, menganalisa dan memanipulasi semua bentuk informasi yang bereferensi geografi.

GIS terdiri atas komponen-komponen yang mendukung proses kerja sebagai suatu sistem informasi yang akurat. Komponen-komponen GIS terdiri dari: 1. Perangkat Keras 2. Perangakt Lunak 3. Data Data dan Informasi Geografi 4. Manajemen [5]. Sedangkan model data dala GIS antara lain: 1. Data Spasial yaitu adalah jenis data yang merepresentasikan aspek-aspek keruangan (menyangkut titik koordinat) dari fenomena atau keadaan yang terdapat di dunia nyata. Data spasial ini sering disebut pula sebagai data posisi, koordinat atau keruangan. 2. Data atribut atau data non spasial adalah jenis data yang merepresentasikan aspek-aspek deskriptid dari fenomena yang dimodelkan. Aspek deskriptif ini mencakup item atau properties dari fenomena yang bersangkutan hingga dimensi waktunya.

Google Maps adalah layanan gratis yang diberikan oleh Google dan sangat popular untuk pemetaan digital berbasiskan web. Aplikasi ini diperkenalkan pada Februari 2005 dan merupakan revolusi penyajian peta dalam bentuk digital [6]. Saat ini Google Maps untuk perangkat android telah mencapai Google Maps v3, yang tentu saja berbeda dengan sebelumnya yaitu Google Maps v1 dan Google Maps v2. Google Maps v3 ini diluncurkan pada maret 2013 dan menawarkan lebih banyak fungsionalitas dari pada versi sebelumnya seperti pembuatan peta 3D [7]. Google Maps menyediakan layanan berupa pemetaan jalan, rute, dan navigasi untuk berbagai rute perjalanan sehingga dapat digunakan untuk mempercepat pencarian sebuah lokasi dalam waktu yang singkat, dan juga menunjukkan jalan mana saja yang harus ditempuh untuk mencapai tujuan [8]. Teknologi Google Maps menggunakan citra satelit untuk melakukan pemetaan objek yang ada di permukaan bumi secara realtime, dalam hal ini peta yang ada pada Google Maps di update dalam kurun waktu tertentu [9].

Penelitian sebelumnya membuat sistem informasi geografis berbasis Android menggunakan bahasa pemrograman Java berupa aplikasi penanda lokasi digital [10]. 
Aplikasi ini memilki beberapa fitur utama seperti input data, menampilkan list data tersimpan, menampilkan rute pada peta, dan mem-backup dan mengimpor data. Hasil penelitian ini merupakan sebuah aplikasi interaktif yang dapat memberikan representasi peta digital dengan titik-titik lokasi berupa marker atau penanda sesuai latitude dan longitude yang diinputkan.

1) Alat dan Bahan

\section{METODE PENELITIAN}

a. Perangkat keras (hardware), yang terdiri dari:

- Laptop Acer dengan spesifikasi Sistem Operasi Windows 10, 64-bit; Prosesor Intel® Core i3, Memory 4GB RAM.

- Smartphone Xiaomi Redmi 4x dengan spesifikasi Android Version Nougat (7.0); Prosesor Quad Core, Memory 3GB RAM, Dual Network Standby, G-Sensor, GPS satellites.

b. Perangkat Lunak (software), yang terdiri dari :

- Google Chrome

- Android Studio

- Java 8 Update 13

2) Arsitektur Sistem

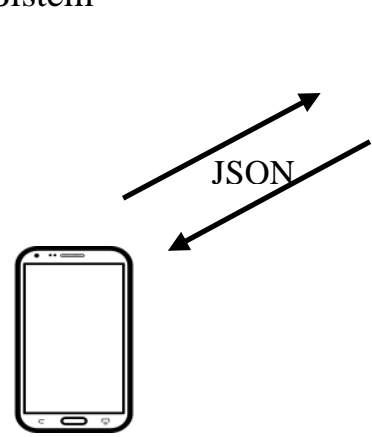

Kurir app

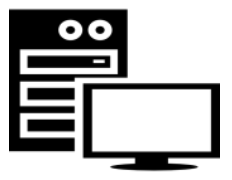

Server

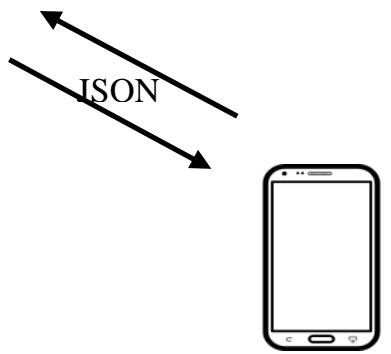

Outlet app

Gambar 2. Arsitektur Sistem Informasi Geografis Pelacakan Kurir

Sistem ini terdiri dari dua aplikasi Android, yaitu aplikasi outlet dan aplikasi kurir. Aplikasi kurir adalah aplikasi yang digunakan kurir untuk menerima order barang baik itu pengiriman maupun penjemputan barang. Aplikasi kurir dapat menerima notifikasi jika ada suatu order, berdasarkan lokasi outlet yang meminta order tersebut. Sehingga sistem dapat menyeleksi pengiriman notifikasi hanya pada 10 kurir terdekat saja. Aplikasi Outlet adalah aplikasi yang digunakan outlet untuk mengorder barang. Jika order telah diterima dan di-accept oleh kurir, maka aplikasi outlet dapat melacak/memantau lokasi kurir sedang berada dimana, estimasi durasi perjalanan dan jarak tempuh. Komunikasi antar aplikasi ini menggunakan API yang terintegerasi dengan backend system berbasis laravel, dengan data berbentuk JSON (JavaScript Object Notation).

3) Activity Diagram

Activity diagram menggambarkan workflow (aliran kerja) atau aktivitas dari sebuah sistem atau proses bisnis [11]. Terdapat tiga entitas pada activity diagram aplikasi ini, yaitu kurir, sistem dan outlet. Setiap komponen memiliki peran masingmaasing dalam activity diagram sehingga membentuk workflow yang utuh, tidak dibagi menjadi beberapa proses terpisah. Activity diagram sistem ditunjukkan pada Gambar 3 . 


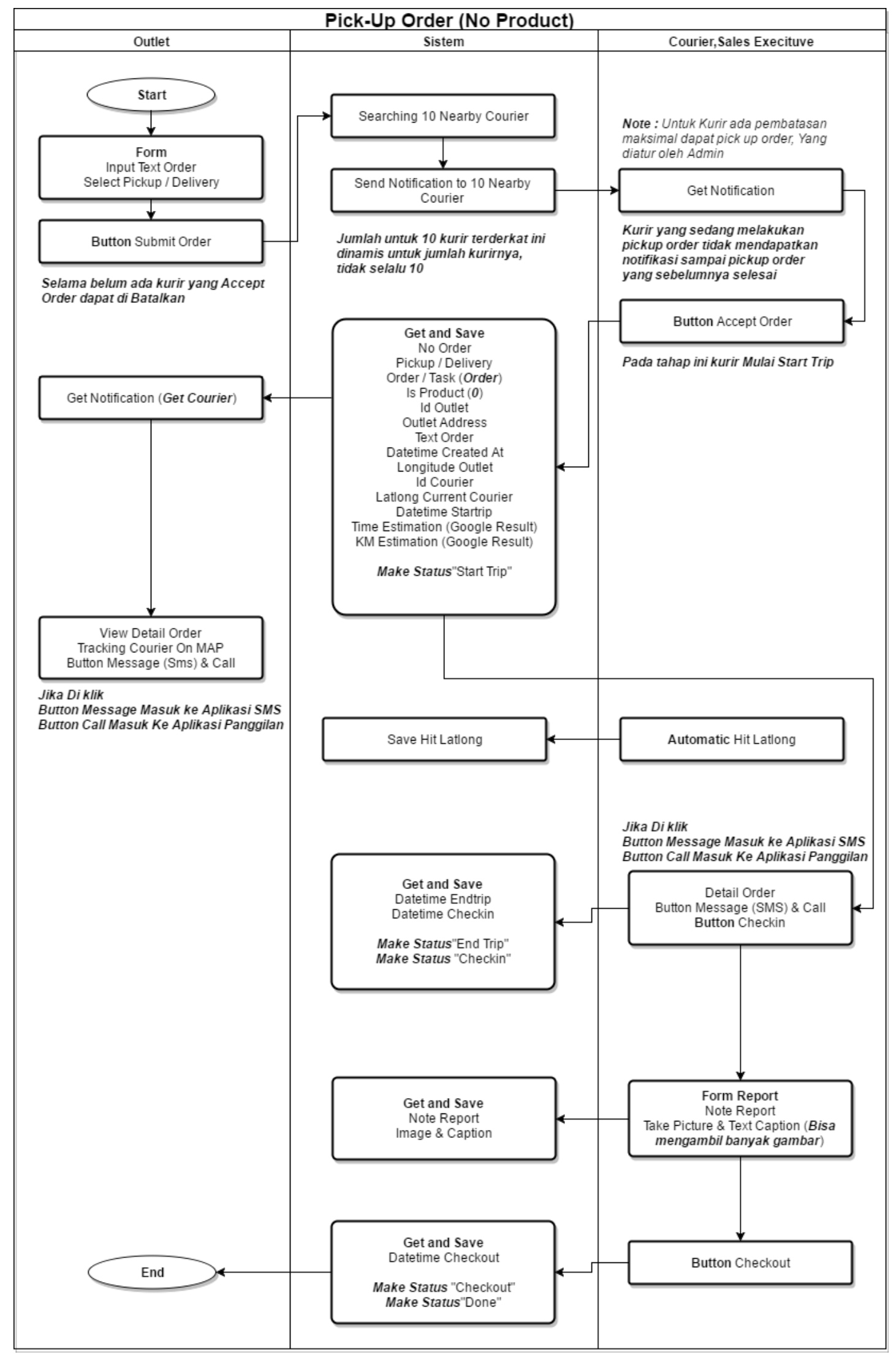

Gambar 3. Activity Diagram Sistem Informasi Geografis Pelacakan Kurir 


\section{HASIL DAN PEMBAHASAN}

1) Implementasi Sistem

Aplikasi ini berperan sebagai platform penghubung antara kurir perusahaan dengan outlet dalam aktivitas permintaan/order, pengiriman barang, return barang, pelaporan ke pusat, logging aktivitas transaksi dan pendataan lokasi outlet secara geografis. Seorang kurir dapat menerima notifikasi order lebih dari satu sebagai task pada hari itu, jadi pada aplikasi kurir ditampilkan daftar task/order yang dapat dia kerjakan (berlokasi di dalam satu kota dengan posisi kurir). Namun kurir tidak bisa accept dua task sekaligus, karena setiap task di accept, harus dikerjakan sampai selesai dengan bukti laporan berupa foto aktivitas transaksi dan pelaporan tersebut hanya bisa dilakukan di area tujuan, jadi kurir tidak bisa memanipulasi laporan tersebut. Tampilan Home, yaitu halaman yang menampilkan daftar task yang bisa dikerjakan kurir dapat dilihat pada Gambar 4.

\begin{tabular}{|c|c|}
\hline 2014817 & $0=0.4 \mathrm{C} 0$ \\
\hline 100600 & 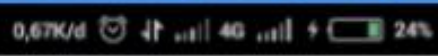 \\
\hline
\end{tabular}

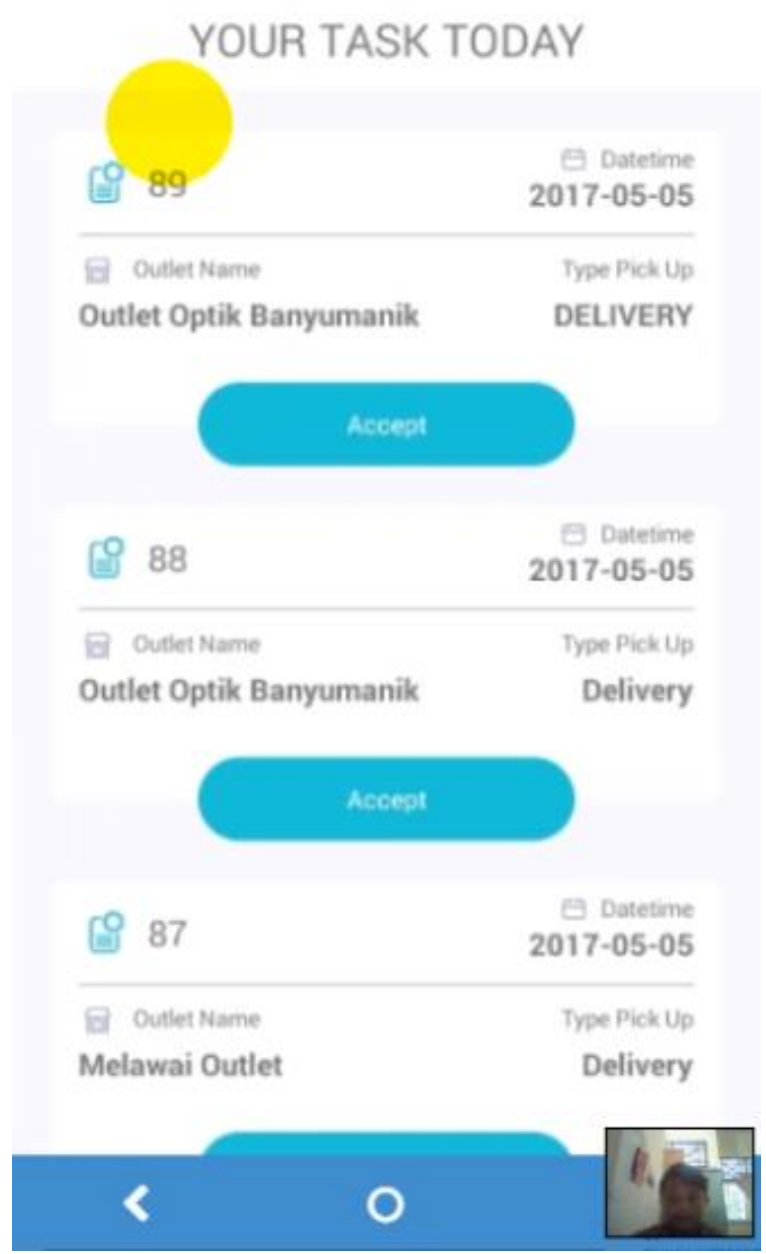

Gambar 4. Halaman utama aplikasi, menampilkan daftar task

Task yang tersedia dalam daftar merupakan hasil seleksi berdasarkan lokasi kurir dan outlet, sehingga yang ditampilkan adalah order dari outlet yang memiliki jarak relatif 
dekat. Setelah tombol accept di klik, aplikasi akan mengarahkan kurir pada detail order terlebih dahulu. Pada detail order ditampilkan maps dengan marker lokasi outlet, alamat tertulis dan data produk yang diminta. Detail order ditampilkan pada gambar 5.

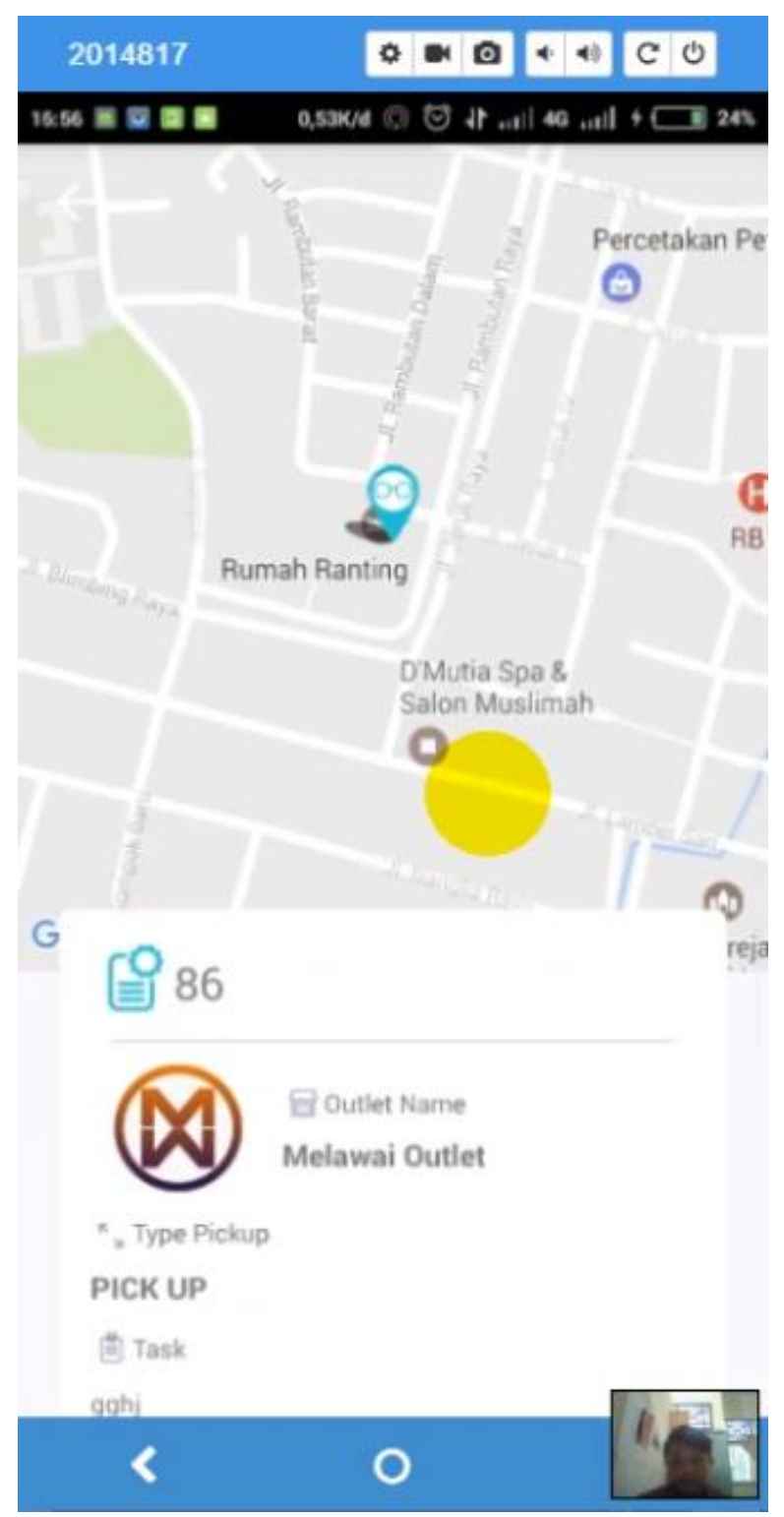

Gambar 5. Halaman detail task

Setelah melihat detail order, kurir dapat melanjutkan task dengan mengklik tombol accept yang terletak di bagian bawah. Jika kurir merasa tidak ingin mengerjakan task tersebut, kurir dapat membatakkannya dengan menekan tombol back. Setelah di-accept kurir diarahkan ke halaman On Process Task, dimana terdapat data geografis yang lebih lengkap, seperti terlihat pada gambar 6. 


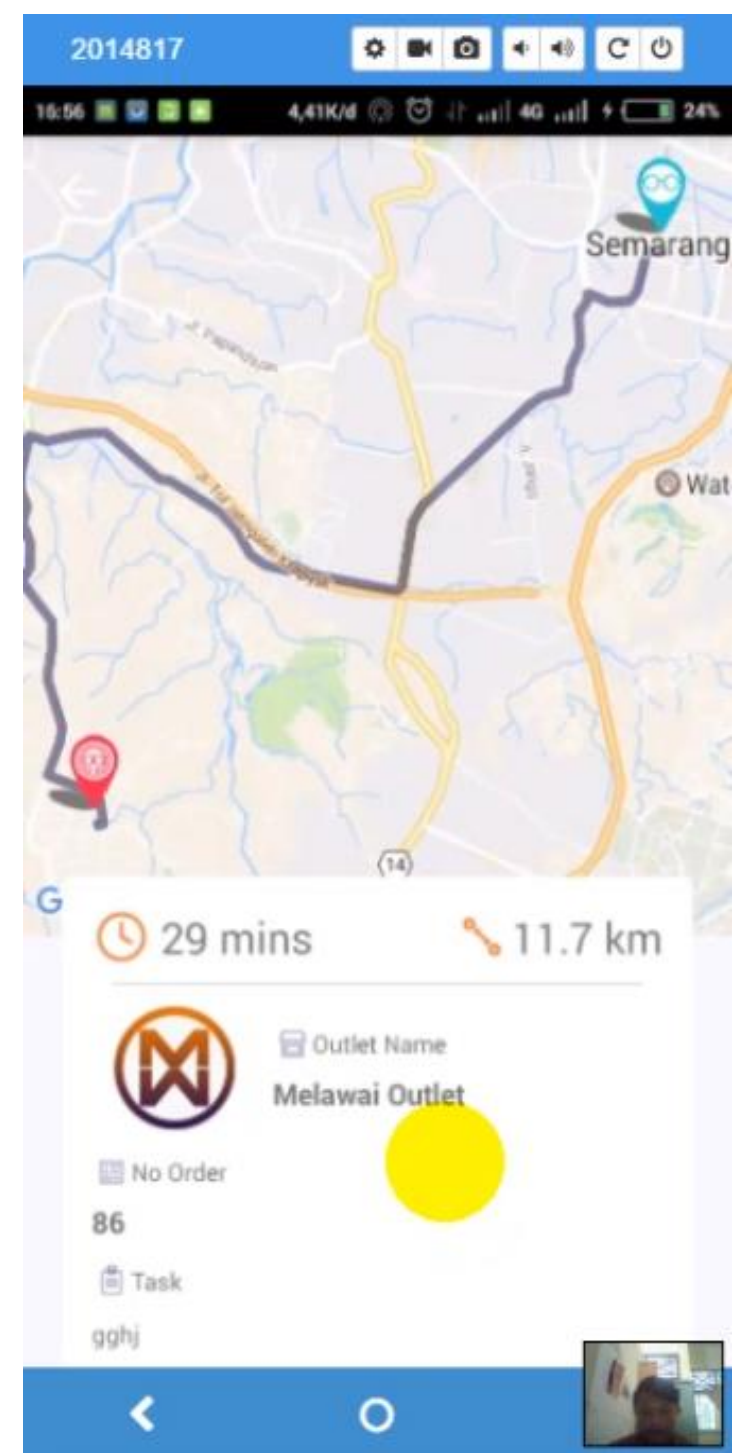

Gambar 6. Halaman On Process Task

Pada halaman On Process Task, ditampilkan rute dari lokasi kurir sampai lokasi outlet berserta marker-nya. Selain itu juga ditampilkan duration, yaitu waktu yang diestimasi google untuk menempuh perjalanan dari lokasi kurir ke outlet dengan melewati rute yang disediakan dan distance yaitu jarak dari kurir ke outlet yang juga ditempuh berdasarkan rute yang disediakan.

2) Analisis Sistem

Analisis dilakukan dengan instrument penelitian sesuai dengan standar ISO 25010 yang meliputi pengujian functional suitability, compatibility, usability, dan performance efficiency.

\section{a.Fuctional Suitability}

Pengujian aspek functional suitability menggunakan test case dengan skala Guttman sebagai skala pengukuran instrumen. Setiap jawaban item instrumen yang menggunakan skala Guttman harus tegas dan konsisten misalnya "Ya" atau "Tidak" (Guritno, Sudaryono, \& Rahardja, 2011, p. 115). Berdasarkan tujuan pembuatan aplikasi ini, didapat beberapa instrumen test case sebagai minimum valuable product yaitu pada tabel 1 . 
Tabel 1. Instrumen test case

\begin{tabular}{|c|l|c|}
\hline No & \multicolumn{1}{|c|}{ Instrumen } & Hasil \\
\hline 1 & Aplikasi dapat memfasilitasi outlet membuat order & Ya \\
\hline 2 & $\begin{array}{l}\text { Aplikasi dapat memfasilitasi kurir menerima dan } \\
\text { mengerjakan task/order }\end{array}$ & Ya \\
\hline 3 & $\begin{array}{l}\text { Aplikasi dapat menampilkan informasi geografis kurir } \\
\text { dan outlet dalam bentuk peta digital atau maps }\end{array}$ & Ya \\
\hline 4 & Aplikasi dapat melacak lokasi kurir secara realtime & Ya \\
\hline 5 & $\begin{array}{l}\text { Aplikasi dapat menyeleksi pengiriman notifikasi dan list } \\
\text { task berdasarkan lokasi aktual kurir }\end{array}$ & Ya \\
\hline
\end{tabular}

Berdasarkan instrumen analisis diatas yang mengacu pada minimum valuable product, menghasilkan data lima instrumen bernilai "Ya", sehingga dapat disimpulkan secara functional suitability aplikasi ini sangat layak.

b. Compatibility

Analisis kualitas untuk aspek compatibility dilakukan dengan melakukan ujicoba secara operasional dengan menginstall aplikasi di berbagai versi sistem operasi android mulai dari versi android android ice cream sandwich, android jelly bean, dan android kitkat. Selanjutnya dilakukan perhitungan skor persentase hasil pengujian dan dicocokkan dengan skala penilaian untuk mengetahui tingkat kualitas aspek compatibility aplikasi.

$$
\text { Persentase Kelayakan }=\frac{\text { Skor yang didapatkan }}{\text { Skor maksimal }} \times 100 \%
$$

Pengujian dilakukan dengan memanfaatkan Google Firebase Test Lab, yaitu cloud platform untuk melakukan testing compatibility aplikasi. Hasil analisis dapat dilihat pada gambar 7 .

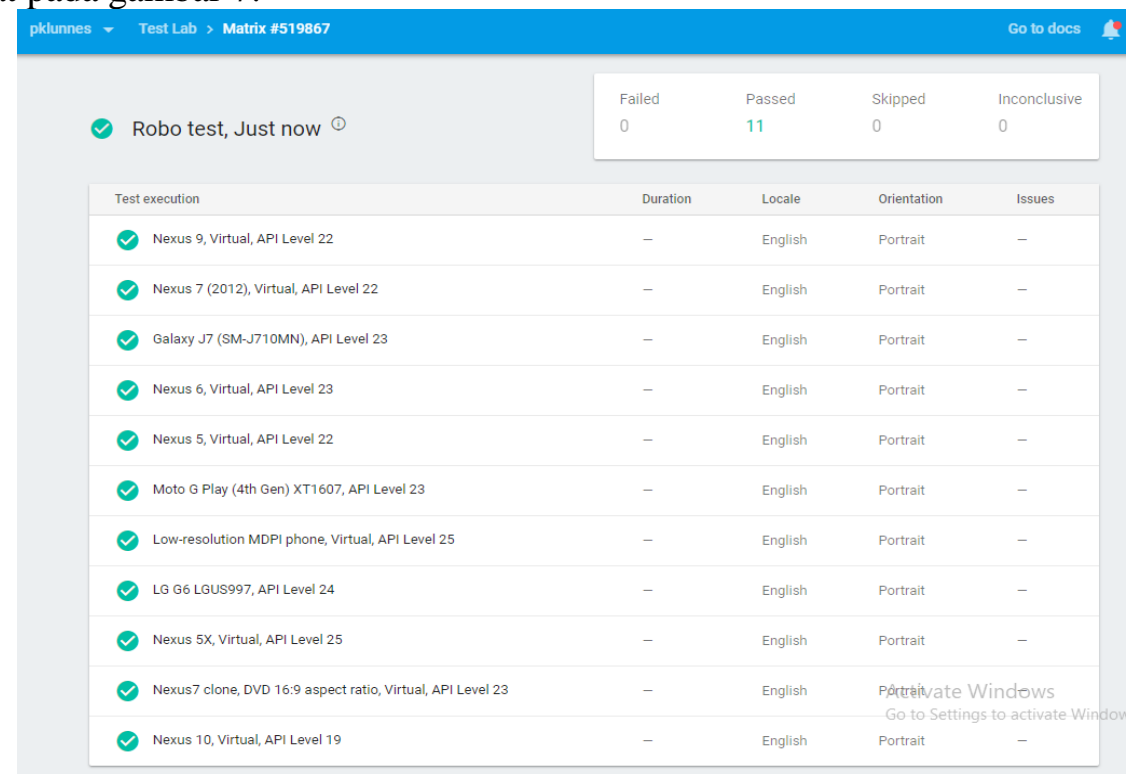

Gambar 7. Hasil uji compatibility dengan Firebase Test Lab

Berdasarkan hasil diatas, dapat dihitung nilai compatibility aplikasi, yaitu:

$$
\text { Presentase kelayakan }=\frac{11}{11} \times 100 \%=100 \%
$$

Tingkat kelayakan berdasarkan analisis compatibility adalah mendapatkan hasil $100 \%$, sehingga dapat dikatakan aplikasi ini sangat layak secara compatibility. 


\section{c.Usability}

Analisis aspek usability adalah pengujian berdasarkan kepuasan pengguna terhadap fasilitas/fitur pada aplikasi. Pada analisis kali ini, nilai kepuasan mengacu pada respon pengguna saat menggunakan aplikasi. Pengguna disini adalah stakeholder yang membutuhkan fasilitas aplikasi Sistem Informasi Geografis untuk membantu aktivitas perusahaan. Versi terbaru dari aplikasi ini yaitu 1.0.3, sudah digunakan oleh end-user dalam waktu kurang lebih empat bulan tanpa komplain baik dari segi stabilitas, fitur, kenyamanan dll, sehingga aplikasi ini sudah dapat dikatakan usable.

d. Performance Efficiency

Analisis kualitas untuk aspek performance efficiency dilakukan dengan menghitung rata-rata waktu respon dari aplikasi untuk mengambil data dari server dan menampilkannya. Hasil tersebut kemudian dikomparasikan dengan tabel kepuasan pengguna yang dikemukakan oleh Hoxmeier \& DiCesare (2000). Pengguna mendapatkan kepuasan tertinggi apabila waktu respon dalam kondisi delay 0 detik sedangkan kepuasan tetap dalam rentang 3 sampai 9 detik dan mengalami penurunan apabila lebih dari 12 detik (Galletta, Henry, McCoy, \& Polak, 2004). Apabila hasil dari perhitungan rata-rata waktu respon kurang dari 9 detik maka dapat disimpulkan aplikasi yang dikembangkan memenuhi aspek performance efficiency.

Tabel 2. Skala Hoxmeier

\begin{tabular}{|l|l|}
\hline \multicolumn{1}{|c|}{ Respon waktu (detik) } & \multicolumn{1}{c|}{ Predikat } \\
\hline$<3$ & Sangat puas \\
\hline $3-9$ & Puas \\
\hline $9-12$ & Cukup puas \\
\hline$>12$ & Tidak Puas \\
\hline
\end{tabular}

Pengujian dilakukan dengan tools yang sama seperti pengujian compatibility yaitu Firebase Test Lab, seperti terlihat pada gambar 8.

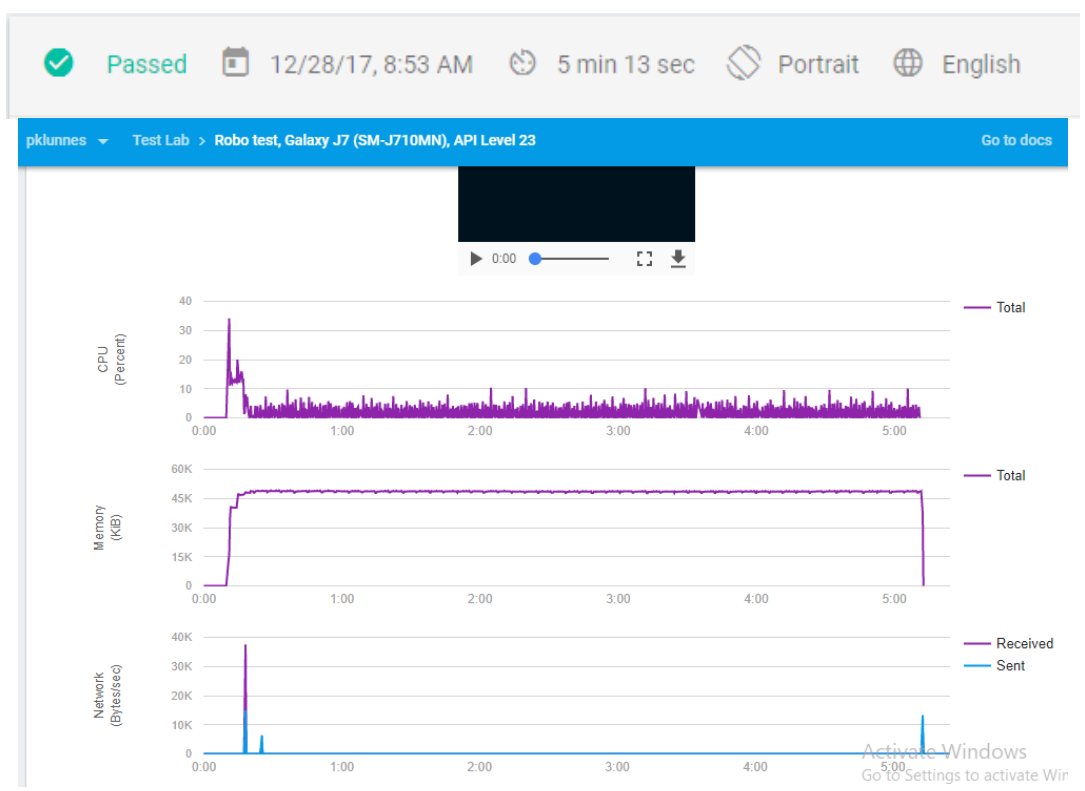

Gambar 8. Hasil performance efficiency test 
Berdasarkan hasil test yang didapat, waktu yang diperlukan untuk loading satu activity yaitu 2 menit 6,5 detik (test diatas dilakukan untuk dua activity), jika dibanding kan dengan skala Hoxmeier, maka mendapatkan hasil sangat puas.

\section{KESIMPULAN}

Berdasarkan hasil dan pembahasan, pembuatan Sistem Informasi Geografis untuk pelacakan kurir secara real time pada platform android dapat dilakukan dengan memanfaatkan Google Maps API yang disediakan Google. Berbagai atribut yang diperlukan telah diproduksi oleh google dalam bentuk rest API JSON, sehingga sangat membantu pembuatan aplikasi GIS sesuai dengan kebutuhan fitur pada aplikasi.

Analisis sistem yang berdasar pada ISO 25010, yaitu pada aspek functional suitability yang menggunakan skala Guttman menghasilkan data $100 \%$ untuk nilai "Ya". Aspek compatibility, dengan menggunakan tools Firebase Test Lab didapat hasil $100 \%$ kompatibel untuk device yang disediakan Firebase. Pada aspek usability, dengan berdasar pada fakta penggunaan tanpa kendala oleh pengguna, didapat hasil aplikasi sangat memuaskan. Pada aspek performance efficiency, didapat nilai efficiency sangat memuaskan karena waktu yang diperlukan untuk loading activity kurang dari 3 detik. Jadi dapat disimpulkan bahwa tingkat kelayakan aplikasi Sistem Informasi Geografis ini sangat layak.

\section{SARAN}

Diharapkan kelemahan secara performance dalam pembuatan fitur pelacakan real time yang memanfaatkan timer berulang dapat diatasi dengan algoritma yang sesuai. Fasilitas ini jika memungkinkan dapat diakomodir oleh Google Services SDK versi terbaru dengan menambahkan class atau method update maps berdasarkan interval tertentu, sehingga developer tidak perlu menggunakan class TimerTask. Sementara yang sudah ada adalah method onLocationChange, yang mana listener ini akan terpanggil ketika lokasi berubah.

\section{UCAPAN TERIMAKASIH}

Penulis mengucapkan terima kasih kepada Universitas Negeri Semarang yang telah memberi dukungan fasilitas terhadap penelitian ini.

\section{DAFTAR PUSTAKA}

[1] Dyah, NR., Arsandy ER. 2015. Sistem Informasi Geografis Tempat Praktek Dokter Spesialis di Provinsi D.I. Yogyakarta Berbasis Web. Jurnal Informatika Mulawarman vol. 10 (1) pp. 65-72.

[2] Safaat, N. 2011. Android:Pemrograman Aplikasi Mobile Smartphone dan Tablet PC Berbasis Android. Bandung: Informatika.

[3] Holla, S., \& Katti, M. M. 2012. Android Based Mobile Application Development And Its Security . International Journal of Computer Trends and Technology.

[4] Kosasi, S. 2014. Sistem Informasi Geografis Pemetaan Tempat Kost Berbasis Web. CSRID Journal. Vol. 6 (3) pp. 171-181.

[5] Prahasta, Eddy. 2002. Konsep-konsep Dasar Sistem Informasi Geografis. Informatika: Bandung. 
[6] Hu, S., \& Dai, T. 2013. Online Map Application Development Using Google Maps API, SQL Database, and ASP.NET. International Journal of Information and Communication Technology Research.

[7] Ariyanti, R., Khairil, Kanedi, I. 2015. Pemanfaatan Google Maps Api Pada Sistem Informasi Geografis Direktori Perguruan Tinggi Di Kota Bengkulu. Jurnal Media Infotama. Vol. 11 (2) pp. 119-129.

[8] Ramadhan, Dr. 2015. Pengembangan dan Analisis Kualitas Aplikasi Mobile School Maps (Moomaps) Berbasis Mobile Application Untuk Pemetaan Universitas di Yogyakarta. Skripsi. Universitas Negeri Yogyakarta.

[9] Anupriya, \& Saxena, M. 2013. An Android Application for Google Map Navigation System Implementing Travelling Salesman Problem. International Journal of Computer \& Organization Trends.

[10] Hati, GM., Suprayogi, A., Sasmito, B. 2013. Aplikasi Penanda Lokasi Peta Digital Berbasis Mobile GIS pada Smartphone Android. Jurnal Geodesi Undip Vol. 2 (4) pp. 2640.

[11] Hendini, A. 2016. Pemodelan Uml Sistem Informasi Monitoring Penjualan dan Stok Barang (Studi Kasus: Distro Zhezha Pontianak). Jurnal Khatulistiwa Informatika, Vol. 4(2) pp. 107-116. 